\title{
Non-Bloody Diarrhea, Fevers and Weight Loss in A 70 Year Old Man
}

\author{
Christina Tofani* and David Kastenberg \\ Thomas Jefferson University Hospital, USA
}

Submission: February 01, 2017; Published: February 14, 2017

"Corresponding author: Christina Tofani, Thomas Jefferson University Hospital, 909 Walnut St, Philadelphia, PA 19107, USA,

Email: christina.tofani@gmail.com

\section{Opinion}

A 70 year-old male with diabetes mellitus and hypertension presented with 6 months of non-bloody diarrhea. He also reported intermittent fevers and a 60-pound weight loss. He denied recent travel or sick contacts. The patient was chronically illappearing with temporal wasting and the remainder of the exam was normal. Laboratory values showed white blood cell count 11.8 thousand $/ \mu \mathrm{L}$, hemoglobin $10.7 \mathrm{~g} / \mathrm{dL}$, albumin $2.9 \mathrm{~g} / \mathrm{dL}$, C-reactive protein level $6.67 \mathrm{mg} / \mathrm{dL}$, positive anti-saccharomyces cerevisiae antibody, and negative anti-neutrophilic cytoplasmic antibodies. Stool samples were negative for bacterial pathogens

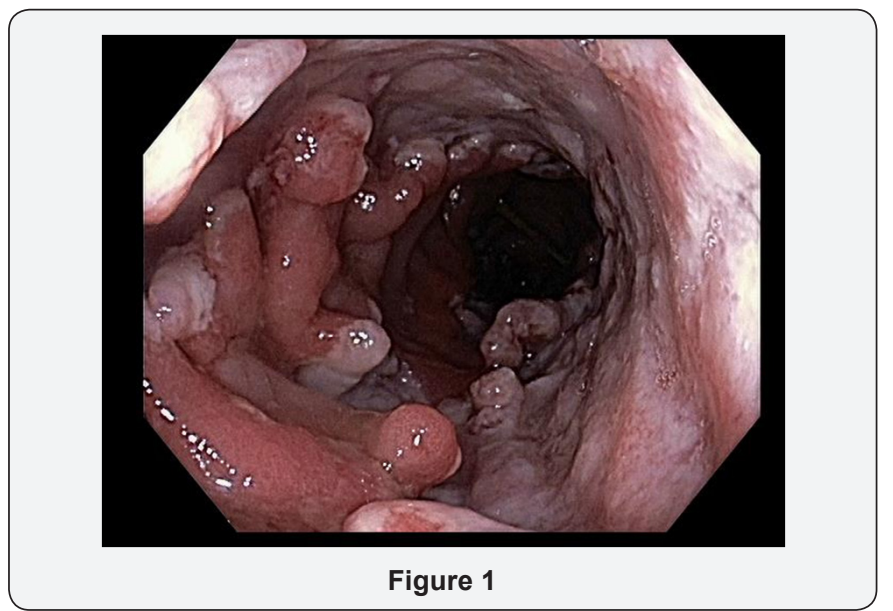

and parasites. Blood cultures and serum cytomegalovirus PCR were negative.

Colonoscopy to the proximal transverse colon found deep ulcerations and heaped up folds with intervening normal mucosa throughout (see images). Colonic biopsies showed ulcerated mucosa with acute and chronic inflammation without granulomas or viral inclusions. MRI enterography revealed normal small bowel. A diagnosis of Crohn's colitis was made, and treatment with prednisone and adalimumab initiated (Figure $1 \& 2)$.

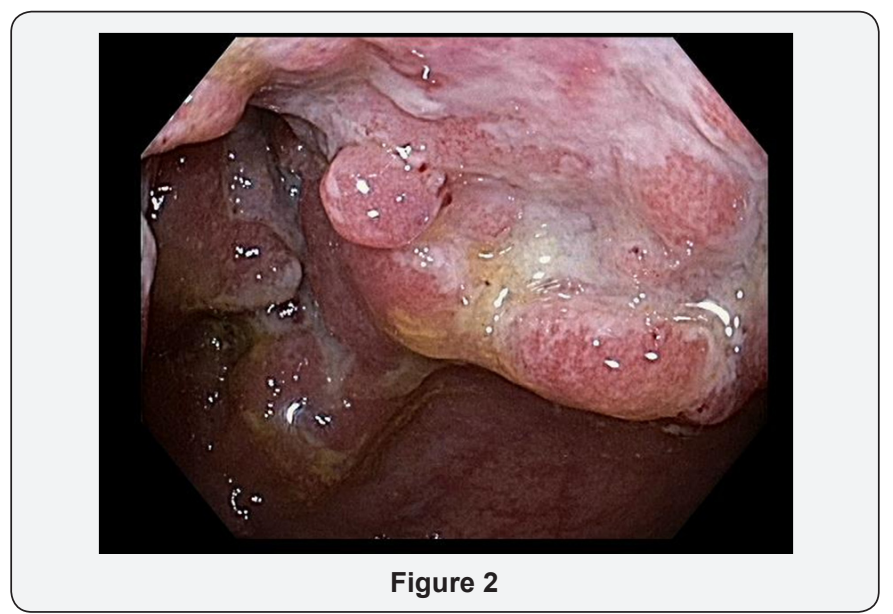




\section{Your next submission with Juniper Publishers} will reach you the below assets

- Quality Editorial service

- Swift Peer Review

- Reprints availability

- E-prints Service

- Manuscript Podcast for convenient understanding

- Global attainment for your research

- Manuscript accessibility in different formats ( Pdf, E-pub, Full Text, Audio)

- Unceasing customer service

Track the below URL for one-step submission https://juniperpublishers.com/online-submission.php 